\title{
Marginality and competitive advantage: The implications of the opening of the CBDs for Chinese businesses
}

\author{
Linda Human* \\ Centre for African Management, Graduate School of Business, University of Cape Town, Private Bag, Rondebosch, \\ 7700 Republic of South Africa \\ K.Y. Fok and N. Chorn \\ Graduate School of Business, University of the Witwatersrand, Johannesburg, 2000 Republic of South Africa
}

Received 7 April 1987

\begin{abstract}
The opening of the CBDs (central business districts) as free trading areas has important implications for the areas of business management, sociology and politics inasmuch as this move represents a significant deviation from past government policies. Before the Johannesburg CBD was declared open for free trading, the Chinese operating within the CBD were afforded the same protection as whites by the barriers imposed upon other 'nonwhite' traders. At the same time, and unlike whites, the Chinese could also move into 'non-white' trading zones without difficulty. The Chinese thus appeared to be operating from a position of strategic advantage, a position which could be attributed to their marginal status in South African society. This article examines the extent to which their marginal position has provided a competitive advantage for the Chinese traders in the Johannesburg CBD as well as the attitudes of these businessmen to the opening of the CBD to all race groups.

Die opening van die sentrale besigheidsgebiede (SBG) hou belangrike besigheidbestuurs-, sosiologiese -en politieke implikasies in siende dat hierdie beleidsverandering sterk afwyk van vorige regeringsbeleid. Chinese handelaars het dieselfde beskerming geniet as Blanke handelaars voordat die Johannesburgse SBG oop verklaar is. Terselfdertyd, en anders as in die geval van Blankes, kon die Chinese handelaars handeldryf in ' $n i e-$ blanke' gebiede sonder enige probleme. Die Chinese het dus 'n strategiese voordeel geniet, 'n posisie verklaarbaar in terme van hul marginale status in die Suid-Afrikaanse samelewing. Hierdie artikel ondersoek die mate waartoe die marginale posisie van Chinese handelaars in Johannesburg se SBG 'n strategiese voordeel skep en ook hul houding ten opsigte van die oopstelling van die SBG vir alle rasse.
\end{abstract}

*To whom correspondence should be addressed

\section{Introduction}

When the Strydom Committee published its report in January 1984, one of its major recommendations was that central business districts (CBDs) should be opened for free trading by all races on application to the local authority and after ministerial approval (Cooper, Schindler, McCaul, Potter and Callum, 1984: 470-473).

In February 1986, two CBDs, one in Johannesburg and one in Durban, became the first free trading areas to be proclaimed as a result of the recommendation. These were to be distinguished from the 'free trading' areas which had been established earlier under section 19 of the Group Areas Act, No. 36 of 1966. Trading areas under section 19 of the Act were 'free' in the sense that mixed racial groups (whites, coloureds, Indians) had been allowed to operate their businesses here, but permits had to be obtained for occupation and ownership by the traders beforehand; no such permits are required under the new legislation. Another difference is that blacks (Africans) are included in the framework of the scheme; however, this group is excluded from ownership of property in such areas and may only rent the premises. By the end of September 1986, seventeen CBDs were proclaimed free trading areas.

The opening of the CBDs as free trading areas has important implications for the areas of business management, sociology, and politics inasmuch as this move represents a significant deviation from past government policies of separate development.
Over the years, government legislation - more specifically, the Group Areas Act - has restricted the trading rights of the different population groups to their own areas. Hence it is illegal, for example, for blacks to occupy or own business premises in a white area, or for whites to trade inside black townships. As a result, the restrictive nature of the current policy of separate development has denied many opportunities to the various population groups. An example to illustrate this point is that of the situation in Soweto: with an adult population estimated to be over 0.61 million, it is a marketer's dream. Yet, its shopping facilities are poor and inadequate to cater for the township's needs (The Black Market Book, 1983). At the same time, those who have the capital to provide the required facilities are unable to do so in the most convenient and cost effective ways because they belong to the 'wrong' race group. The consumer from Soweto therefore has to rely on shopping trips to other centres, such as the Johannesburg CBD, to make his or her purchases. On the other hand, black entrepreneurs are unable to operate outside the bounds of their own areas even if opportunities exist elsewhere. From the aspect of marketing, an effective barrier to entry has been created. There are various ways (for example, by the use of nominees) to overcome this kind of barrier, but they are often costly, risky and usually illegal.

One cannot deny the fact that non-white traders have penetrated into white areas, and vice versa; but under 
the current form of the Group Areas Act of 1966, their presence in such areas is regarded as 'temporary' (until facilities become available in their own areas). Hence special permission, in the form of a permit from the Minister of Community Development, is required in each case before a trading licence is granted in areas not zoned for the racial group of the businessman concerned. The overall result is one of dislocation and resettlement of the traders, some having to give up businesses that had been established for several decades or generations.

Owing to the extent of their commercial involvèment, especially in the CBDs of the major towns and cities of the country, Indians have been more directly affected by the Act than the other population groups (Lemon, 1976: 114-117). For example, figures for the period until the end of December 1983, indicate that 22524 Indian, 54 white, and 187 coloured traders had been moved from business premises since the commencement of the Act (Cooper, et al., 1985: 470). On the other hand, another population group, which is often compared to the Indians (see Human, 1984: 55; Horrell, 1960: 143), appears to have overcome some of the hurdles of the Act. Figures released in 1975 revealed that although 620 Chinese traders were 'disqualified' under the Act, only one had been resettled (Horrell \& Hodgson, 1976: 74). During that same period, 984 Indians out of the 5058 who had been disqualified were resettled - a ratio of almost one in every five. One of the reasons for the Chinese not being resettled was most probably that of the lack of 'own' areas (except for those in Port Elizabeth and Uitenhage in 1975) for this population group. For the same reason, Chinese were 'free' to trade anywhere except in the Orange Free State.

Chinese businesses described by such authors as Dellatola (1977) were most likely to be situated in areas zoned for whites. Although little has been written about the situation, it is known that Chinese-owned businesses have also been established inside non-white areas such as Alexandra (a black township) and Kliptown (a coloured township) on the outskirts of Johannesburg, Korsten (a coloured suburb) in Port Elizabeth, and the Asiatic bazaar of Boksburg. Therefore, it would appear somewhat paradoxically that Chinese business owners enjoy certain advantages or 'privileges' that even whites have not been accorded.

The position occupied by the Chinese in this country is a strange one indeed (see Collins, 1970: 67). For example, under any statute which separates South Africa's population into racial groups (e.g. the Group Areas Act, the Electoral Act, or the Population Registration Act), a Chinese person has always been classified as 'non-white' and is thus legally excluded from the 'privileges' and rights that are reserved for whites. However, certain 'white privileges', such as ownership and occupation of land in a white area, were often easily granted on application to the appropriate authorities. The Chinese are also able to participate in most social activities and occupations historically reserved for whites. Thus, the position of the Chinese in a legal sense differs greatly from their position in a practical sense. Although the Chinese exist on 'privileges' rather than rights (Human, 1984; Yap, 1977), they can, in effect, do most of the things that white people can do. The position of the Chinese in South African society could thus be regarded as 'marginal'. Although this kind of position appears to offer certain marketing or business advantages, it is not altog ether an enviable one because of the uncertainty associated with it.

Even so, it would appear that before the Johannesburg CBD was declared open for free trading, the Chinese operating within the CBD were afforded the same protection as whites by the barriers imposed upon the other non-white traders. At the same time, the Chinese could move into non-white trading zones without difficulty if they so desired. For white traders, the barriers to this were much more formidable. For these reasons then, the Chinese had a competitive advantage over other traders attributable to their marginal position. As a result of the opening of the CBD's for free trading, intuition suggests that this advantage has been eroded, and their position been weakened. If 'non-white' areas become free trading areas as well, the marginal position of the Chinese will no longer be relevant in the penetration of trade barriers. Quite simply, the barriers to entry would no longer exist.

The purpose of this article is to examine the extent to which their marginal position has provided competitive advantage to the Chinese traders in the Johannesburg CBD and the attitudes of these businessmen to the opening of the CBD. In other words, we examine the competitive advantage provided by the barriers of the Group Areas Act and the effects of the recent removal of these barriers on Chinese businessmen. In order to do this, we must first clarify the concepts of competitive advantage and marginality before discussing our research findings.

\section{Marginality}

The concept of marginality was originally introduced by Park (1928) and subsequently developed by Stonequist (1937). Work in this area was continued by Gordon (1964). In essence, the concept of 'the marginal man' is used to refer to a person who stands on the boundary between two or more groups but who cannot fully identify with either group. He is someone who occupies an inconsistent position. This marginal position on a sociological or structural level may in turn lead to personality traits such as insecurity, moodiness, hypersensitivity and excessive self-consciousness. These personality traits, which will vary according to the ability of specific individuals to cope with their sociologically marginal position, are known as 'Psychological marginality'.

For Dickie-Clark (1966: 47-48), the marginal situation was regarded as 'an hierarchical situation in which there (is) any inconsistency in the rankings of the matters falling within the scope of area regulated by the hierarchy. This inconsistency is taken as the essential core of sociological marginality.' "Psychological marginality" "consist(s) simply of the specific attitudes of people to being in these situations...these attitudes can be held without personal maladjustment or undue inner turmoil 
or emotional imbalance' (Dickie-Clark, 1966: 191).

Johnston (1976), extrapolating from the major theories on marginality, suggested the following characteristics of the marginal situation:-

1) A bi-cultural milieu arranged in a two-tier hierarchy in which the ethnic culture is judged as inferior;

2) Where the ethnic group members have achieved a certain level of assimilation;

3) Where the assimilated individuals are rejected by members of the host group; and

4) Where there is uncertainty amongst the ethnic group members as to the choice between the ethnic and the dominant culture even if membership of both is open.

The marginal position of the Chinese community in South Africa was examined by Smedley (now Human) (1978). Her conclusion was that the Chinese more or less fulfilled the marginality-provoking conditions described by Johnston (1976) inasmuch as:-

1) A two-tier hierarchy was identified as the division between white and other-than-white in South African society with Chinese people historically falling within the latter group.

2) A certain level of assimilation into white South African society was detectable although such assimilation was hampered by both 'non-white' status and the ambiguity of official attitudes towards the Chinese.

3) Rejection of assimilated individuals was marked by the ambiguous and often illogical attitudes of the authorities at both the formal and informal level.

4) The uncertainty in choice of group by the Chinese was indicated by their willingness to identify with the white group on a social level but an unwillingness to give up their identity as Chinese (Smedley, 1978: 84-86).

This situation was summed up by Smedley (1978: 87) as follows:- 'Such marginality would appear to be caused by the fact that the white population group intermittently treats the Chinese as equal or inferior at various levels of co-existence, inconsistency perhaps constituting the essential core of marginality'.

While it can be said that the Chinese, as a community, occupy a marginal position, it does not automatically follow that Chinese traders are conducting their business from a position of marginality. However, there are indications that the business situation of the Chinese may be similar to that of the Chinese community as a whole:-

Firstly, in terms of the Group Areas Act, the owner of any business may not occupy land outside of his own designated area unless it is under permit. In the case of the owner being a company, then the racial characteristics of the individual or group holding the controlling interests of the company are taken as the racial characteristics of the company (van Reenen, 1981: 135).

The Group Areas Act has also classified whites as a separate group from 'non-whites', with the 'non-white' group, according to Johnston's (1976) criteria, being judged as inferior. However, in terms of designated trading areas mentioned above, there is a lack of specific trading areas for Chinese (except in Port Elizabeth and, for a short time, in the towns of Uitenhage and Kimberley). The other 'non-white' and white groups possessed areas into which they were zoned. By way of contrast, the Chinese, although 'disqualified' had few areas into which to move. Chinese traders therefore continued to occupy and own premises in areas belonging to other groups. Many such areas were white although in terms of the legislation, the Chinese were classified as 'non-white'. The permit system, in turn, reinforced this inconsistent situation inasmuch as it legitimized operation in one area from which, in all other ways, the Chinese were legally barred. Thus, we have a situation in which the Chinese are part of an inferior rung in a twotier hierarchy, in which they are at times accepted and at others rejected by the dominant group; a group which is willing to trade in white areas and identify with whites on a social level, but who are unwilling to give up their identity as Chinese, not only, one suspects, because of a pride in Chinese culture, but also because of their inconsistent and ambiguous treatment by the authorities.

\section{Competitive advantage}

The Chinese, more than any other group, appear to have been able to penetrate and overcome the barriers of separate trading areas set up by legislation. In the competitive environment of business, such a position appears to represent an advantage over the other groups who were more restricted in their choices. For the purposes of this study, competitive advantage can be regarded as "competing from a position of strength against the weakness of competitors' (Arnold, Capella \& Smith, 1983: 143).

Industries may be defined and analysed in terms of five basic competitive forces (Porter, 1980):

the threat of new entrants

the threat of substitute products

the bargaining power of buyers

the bargaining power of suppliers

the intensity of the rivalry amongst existing competitors.

The interaction of these forces will determine the dynamics of the industry structure (see Figure 1). In addition, the collective strength of these forces will determine the potential profitability of competing firms. A change in any of these forces will therefore affect the overall industry structure and hence the expected returns.

The threat of entry is a function of the barriers to entry of the industry. The higher these barriers, the more difficult potential entry becomes, and the less the threat of new competitors entering the industry. Examples of entry barriers include economies of scale, capital requirements and government legislation.

The threat of substitute products represents the relative ease with which buyers are able to purchase and consume an alternative product capable of performing the same function(s) as the product of the industry. The higher the threat of substitutes the greater the pressure on existing competitors to supply 'their' products at a competitive price. Factors determining the threat of substitution include the relative prices of substitutes, and the costs to buyers of making a change in their purchase and consumption behaviour.

The bargaining power of buyers measures the relative dependence of the competing firms on the buyers. The 


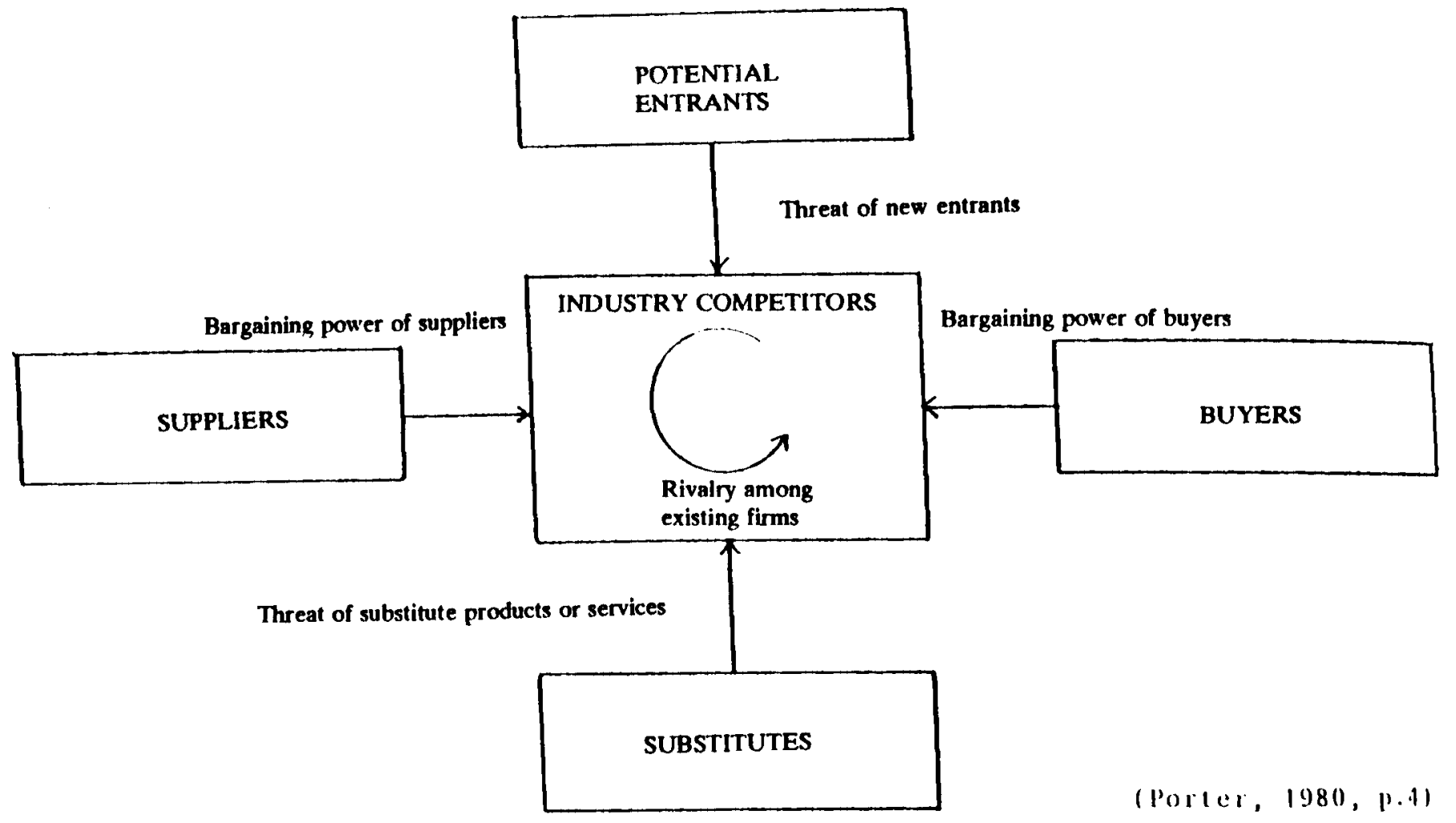

Figure 1 The five forces driving competition

greater the buyers bargaining power, the better their ability to derive increases in value-for-money, either by depressing prices, or by forcing quality improvement without corresponding price increases. Factors such as the buyers' size relative to the firms in the industry, would impact on their bargaining power.

The bargaining power of suppliers involves a similar set of factors as those of the buyers. Suppliers' bargaining power derives from factors such as supplier concentration and the presence or absence of substitute inputs.

Finally, the rivalry amongst the existing competitors is usually manifested by way of a variety of positioning and marketing strategies, which seek to improve the relative position of firms over each other. The intensity of this rivalry is dependent on factors such as the rate of growth within the industry, the degree of product or service differentiation, and assistance of barriers to exit.

Porter $(1980,1985)$ acknowledges that firms are able to improve their relative positions within industries by way of these strategies. Indeed, some firms may even be able to change the 'rules of competition' as a result of innovative and creative approaches (Porter, 1980). Three generic strategies describe the range of alternatives open to firms in these positions (Porter, 1985: 11):

i) Overall cost leadership: where the firm endeavours to gain maximum benefit from economies of scale, and achieves a dominant low-cost position within the whole industry.

ii) Differentiation: where the firm obtains its competitive advantage by producing a product(s) or service(s) which is uniquely designed to better meet the needs of its market(s) than its competitors. iii) Focus: where the firm combines a narrow market focus with high product/service differentiation or cost advantage, to meet the needs of buyers more effectively or efficiently than other competitors.

Industries may be viewed as a collection of smaller segments made up of relatively homogeneous groups of products, buyers or buyers' needs (Abell, 1980). Porter (1985: 231-272) argues that these segments come about as a result of differences in the basic competitive forces from one part of the industry to another. Thus, an industry may be viewed in terms of an array of these variables. An example might include the various segments made up of product varieties on the one hand, and buyers' needs on the other. Moving from one of these segments to another alters the make-up of the basic competitive forces, because of the changes in each case in competitor rivalry, buyer power and so on. It follows, therefore, that the competitive position of a firm would alter from one segment to another, because of its resources and skills relative to the basic competitive forces of the industry segment.

The theory of industry segmentation above may be used to construct an industry segmentation matrix which reflects the provisions of the Group Areas Act. Using the segmentation variables of rival groups and racial areas, an industry segmentation matrix may be constructed which permits the examination of the competitive position of each racial group (see Figure 2). In accordance with the Act, each group is allocated areas of its own, from which a person belonging to another group is disqualified from occupying land or premises unless it is under the authority of a permit (van Reenen, 1981). Each segment, therefore, has an entry barrier by way of government legislation. The entry barrier is low if the 
GROUPS

\begin{tabular}{|c|c|c|c|c|c|}
\hline & WHITE & CHINESE & INDIAN & COLOURED & BLACK \\
\hline WHITE & WHITE & $\begin{array}{l}\text { Chinese in } \\
\text { white aren }\end{array}$ & & & \\
\hline CHINESE & NULL & NULL & NULL & NULL & NULL \\
\hline INDIAN & & $\begin{array}{l}\text { Clinese in } \\
\text { Indiats area }\end{array}$ & INDIAN & & \\
\hline COLOURED & & $\begin{array}{l}\text { Chinese in } \\
\text { coltured } \\
\text { area }\end{array}$ & & COLOURED & \\
\hline BLACK & & $\begin{array}{l}\text { Climese in } \\
\text { black area }\end{array}$ & & & BLACK \\
\hline
\end{tabular}

Figure 2 Segmentation matrix of the Group Areas Act

area corresponds with the population group to which the trader belongs. With the introduction of the permit system, the relative 'height' of the entry barrier is dependent on the attitude and discretion of the Department of Community Development at the time. Hence, the barriers to entry are low if permits are readily issued or Government attitudes are tolerant; high if the possibility of refusal is high.

In the case of the Chinese, Figure 2 becomes more complicated. In certain regions, such as Johannesburg or Pretoria, the group exists but not the area. Hence the cells along the Chinese category of the segmentation variable of areas become null cells because combinations with Chinese areas are not feasible. However, the Chinese have been able to trade in both white and nonwhite areas. Where permits were required, it was a matter of formality: thus it is implied that the Chinese have lower barriers to entry into the different areas belonging to other groups. There is thus a greater choice of trading areas (segments) for the Chinese and greater freedom from the mobility barrier which prevents one group from occupying the area of another group. The significance of this is that the choices of strategic options have been considerably widened. The implications are best viewed in terms of the three generic strategic approaches described by Porter (1985) in coping with the five competitive forces: overall cost leadership, differentiation and focus.

In all three strategic applications, geographic location may be an important factor for consideration. For example, certain cost elements such as labour, transport, rental, etc. are often relative to where the business is situated (Porter, 1985: 82-83); uniqueness may come from where the business is located (Porter, 1985: 128). Groups that are restricted to certain locations may be able to determine that lower cost or differentiation can be achieved through relocating or setting up a business elsewhere. However, if the area is situated in a district proclaimed for another. racial group there is little that can be done if a permit is not granted. The focus strategy is built around serving a particular target very well (Porter, 1980: 38). It is here that the position of the Chinese is notably useful. Where the target is geographically located, the advantage of the Chinese, over other groups, is obvious: their potential target can be anywhere in white or non-white areas, whereas other businessmen can only consider those in their own area.

So far, the position of the Chinese has only been examined in terms of the competitive force of the threat of entry. However, that is not to say that this is the only force that has any appreciable effect on the Chinese traders or that none of the other four forces are less important. The other forces, viz. rivalry, sellers, buyers, and substitutes, may, in some instances, be so powerful that the advantages gained (as a result of a lower barrier to entry) are not enough to compensate for the adverse conditions brought about. Another point to note is that the barrier to entry as addressed by the permit system, or other legislation, is not the only barrier to be faced by the traders; and neither are barriers the only elements that constitute the force that is the threat of entry (see Porter, 1980; 1985). It is important to bear in mind that entry barriers such as economies of scale, switching cost, expected retaliation, etc. (Porter, 1980), may play a crucial role in the determination of the strength of the force.

Let us now investigate the attitudes of Chinese traders to the opening of the Johannesburg CBD vis-à-vis their perceptions of the competitive advantage provided by their marginal position.

\section{Research method}

Owing to a lack of statistical data on the number of Chinese-owned businesses in the Johannesburg CBD, we were unable to identify all the traders in the area. Of the 63 Chinese traders identified, 29 were interviewed by means of a semi-structured interview schedule. The following findings are of note:-

\section{Distribution of businesses}

From observations and notes gathered during the interviews, it would appear that the highest concentration of Chinese businesses is situated on the western border of the Johannesburg CBD in an area known as Ferreirastown. Popularly called 'Ma-Lei-Kum' (from the pidgin 'Malay Camp' - which had been situated in the area in the early mining days), this Chinatown of Johannesburg consists of 15 - 20(the number depends on whether certain businesses which were situated two or three blocks away could be included) Chinese-owned businesses $(23,4-31,3 \%$ of the total businesses identified). These include restaurants, wholesalers, delicatessens, travel agencies, gift shops, and a drycleaning depot. Nine of the businesses interviewed for the study were situated in this area. Of these, six were located in this area for historical reasons: they were family businesses which had been handed down to the present owners. Because this group was located where identification could readily be made, the possibility of the traders here being overrepresented must be borne in mind.

Although information is incomplete, it would appear that the reason for the concentration of Chinese traders and residents here is also historical. It would appear that 
since the early Chinese merchants settled in Johannesburg (c.1900), the area had been a popular spot for social gatherings with several Chinese clubs being established there. The Chinese character was entrenched in 1917 when the Chinese United Club Purchased an existing hotel to be used as its recreational centre and to provide a place of residence for its members. Subsequently, the first stores were opened in the 1920s. However, it was not until after the Second World War that the number of shops increased rapidly; only to decrease again in recent years as a result of several buildings being demolished.

Apart from this area, it appeared that no other identifiable patterns of distribution exist except for the usual strategic locations, e.g. a large number of the butcheries and down-market foodstores were situated in close proximity to black and coloured bus terminals and railway stations, or where there was a large volume of black pedestrian traffic; the upmarket gift shops and restaurants were located in areas frequented or associated with white shoppers or patrons.

If retailing is defined as 'all business activities that involve the sale of goods or services to the ultimate consumer for personal, family, or household use' (Arnold, et al. 1983: 4), then all, except two, of the respondents interviewed for the study were operating in the retail sector of the market. The other two respondents were wholesalers. Of the retailers interviewed, seven were in the take-away/delicatessen/cafe category, seven butcheries, four gift shops, five restaurants, two shoe repairs, one an electrical appliance store, and one a motor spares dealer.

In the majority of cases (17 out of 29 interviewed $58,6 \%$ ), the legal owner of the business was the sole proprietor; eight $(27,6 \%)$ of the businesses were owned by partnerships; four $(13,8 \%)$ were private companies. There were no public companies among those interviewed. All the partners of the partnerships were Chinese. The majority shareholders of the private companies were also Chinese, but it is not known whether there were any non-Chinese among the minority shareholders. All of the businesses were therefore essentially Chinese in character.

Very subjective standards were used to judge the size of the businesses. A single measurement could not be employed because of the vastly different categories of products and services, which could not be compared to each other. In terms of the usual industry standards (number of branches, number of employees, etc.), the majority of respondents regarded their businesses as of small to medium size. One respondent (who was the major shareholder in a private company which operated a chain of five butcheries within the CBD) regarded his business as being the largest of its kind in Johannesburg - in terms of market share (of the black retail meat market) and turnover. Although data on the size of the businesses are subjective, they are consistent with Human's (1984: 54) notion that Chinese businesses remain quite small.

Twenty-six of the premises occupied by the businesses were rented or leased. Three of the respondents stated
Table 1 Age of businesses

\begin{tabular}{lc}
\hline Year started & Number \\
\hline Before 1960 & 9 \\
$1960-1969$ & 4 \\
$1970-1979$ & 5 \\
$1980-1983$ & 3 \\
$1984-1986^{\circ}$ & 8 \\
Total & 29 \\
\hline "After abolition of permit system for the \\
Chinese in 1984
\end{tabular}

that they owned the building from which they operated. Two of the three buildings had been in the possession of the respective families for over thirty years, while the third was purchased by a private company in 1983. In terms of the Group Areas Act, the premises were legally occupied in all cases by the owners of the businesses. Where occupation had taken place before 1984, it was under the authority of a permit: in the case of rented premises, the only permit required was for occupation of the premises; where the building was purchased, two permits were required, one for the purchase of the property, the other for the purpose of occupation. These permits had to be presented to the licensing authorities before a trading licence could be granted. This is consistent with the requirements of the Group Areas Act (van Reenen, 1981: 267-279).

The oldest business in the sample had been in operation since the 1920s. At the time of the interview, it was being managed by the grandson of the original founder. The most recent of the businesses was opened in January 1986. The majority of the businesses were, however, over one year old (Table 1).

\section{Origins of owners and their businesses}

Consolidating the case histories of the respondents, it was found that at least $16(55,2 \%)$ of the 29 respondents, or their parents, had previously traded or owned businesses in non-white areas before opening their current businesses in the Johannesburg CBD. A surprising fact also emerged in that twelve $(75,0 \%)$ of the 16 respondents had their grounding or their parents had had businesses in the area of Sophiatown - which had formerly been a mixed township that was subsequently proclaimed a white area and underwent a massive renewal programme. Among the other non-white areas which were mentioned by the respondents (including those who had been in Sophiatown) were Kliptown, Alexandra, Riverlea, and Newclare. Six of the respondents had traded in more than one of these areas.

From the large number of families that were uprooted and removed from the area (Horrell, 1957: 105); by the extraordinarily high percentage of respondents who had their first experience of business there and judging by the comments of the respondents, it would appear that Sophiatown was one of the most traumatic events of removals that directly affected the Chinese in the region of 
Johannesburg. It was of interest to trace the subsequent movements of this group as no area under the Group Areas Act had been set aside for them. From the interviews, the respondents (or their parents) who originated from Sophiatown took one of several courses before settling down in their current businesses in the CBD: (i) some went into employment with white or other Chinese businesses, often as clerks, salesmen, representatives, or storemen; (ii) those who had enough capital to restart sought alternative business sites in white or non-white areas; (iii) those who did not find either of these alternatives feasible were forced to resort to fah-fee(an illegal form of gambling with numbers) and other illegal activities in order to earn a living; (iv) most however, did all or a combination of these before opening their current business in the Johannesburg CBD.

From the interviews, it was gathered that the respondents who resettled in white areas immediately after they left Sophiatown did so because:

(a) Opportunities, such as vacant premises or an owner wishing to sell his business, were available at the time. This appeared to be the major reason as it was cited by most of the respondents who made the move of opening a new business in a white area.

(b) Similar developments to those which had occurred in Sophiatown might have arisen in other non-white areas. Non-white townships were therefore avoided. Hence it was implied that white areas were seen as providing a more stable environment.

(c) 'White areas were better situated to do non-white business than non-white areas'. The meaning of this is that certain white areas, such as industrial sites and commercial zones, were better and more conveniently located to serve the non-white workers whose employers were there.

The respondents who had previously moved from Sophiatown into the non-white townships did so because:

(a) Some tried to follow the customers to where they were resettled - in an attempt to salvage at least part of the business that had been lost. This was especially true in the case of moves into the coloured townships because it would appear that Chinese were not easily granted business rights inside the black areas of Soweto and were hence prevented from trading there even if they had wished to do so.

(b) Rental was cheap compared with that of the white areas. This was related to the availability of working capital, which had been depleted by the dislocation of the original customer base.

(c) Profit margins were higher. There were often only a few stores in the vicinity; hence competition was limited and the only alternative shopping facilities were inconveniently located. Even where similar stores were located nearby, higher prices could still be charged because these other stores were often in identical positions and unlikely to drop the general level of their prices to below that of the large supermarkets in the city.

(d) It was the only alternative as seen by the traders at the time. This again, was related to the availability of working capital and to other opportunities.
Turning to the respondents who had originated from non-white areas, (but not from Sophiatown), the factors of cheap rental and higher profit margins were also cited as reasons for trading in those areas, whether the business had been handed down from parents (or relatives) or where the respondents had been the founder.

The reasons for moving out of a non-white area into the CBD or another white area were cited as:

(a) Unstable conditions, high crime rates and politicallyinspired unrest, where stores were looted and even burned down.

(b) Poor facilities: security was often at risk when banking activities had to be carried out; some suppliers did not deliver goods to these areas either because of the unstable conditions or because orders were too small; where the trader lived on premises behind the shop, children had to be transported to and back from school by parents because other modes of transport were unavailable or unsafe.

(c) Long hours. Trading in non-white areas often meant opening from early in the morning to late at night and for seven days a week because of the shopping habits of the customers.

(d) No opportunities for expansion. Although shopping facilities were poor, certain traders viewed the market as saturated because of the limited population of the area. (e) Changing habits of the customers. With more nonwhites owning cars, and with the improvement of taxi services, the customer trend has changed to one of shopping in other areas, such as the Johannesburg CBD, where there are more goods on offer and at cheaper prices.

(f) Clearance of slums. Areas such as Newclare, Alexandra, and Kliptown were subjected to renewal during the past decade. The premises occupied by the stores were often old and dilapidated; thus the traders were forced to move elsewhere when these premises had to be demolished.

In moving from the non-white areas into the CBD of Johannesburg, the reasons for doing so were often the converse of the reasons for leaving the non-white areas: viz. conditions more stable; better and safer facilities; shorter working hours; consistency in customer shopping habits; and more business opportunities.

The respondents who have never traded in non-white areas before could be categorized into three major groups: (i) those who were in the CBD for historical reasons because the family business had been in the area for decades, often having occupied the same site since it was opened; (ii) those who had a product or skill to offer and viewed the CBD as compatible with their abilities and aims; and (iii) those who saw a gap in the market within the CBD and set about to fill this gap. The latter two categories of traders either purchased existing businesses to fulfil their objectives or they started new businesses by occupying vacant premises.

\section{Trading rights of the Chinese}

The Chinese previously required a permit to trade in white areas. According to respondents who had been 
granted permits, conditions were attached that the right of occupancy (or acquisition) was not transferable and the concession was valid until withdrawn by the Minister of Community Development. This was taken to mean that if another Chinese person (including someone from the immediate family) was to take over the business, the prospective owner would have to reapply for another permit. Further, if the Minister exercised his right to withdraw the permit, that would have meant the end of the business. Another condition of the permit was that the property had to be occupied or acquired within a certain period of time (usually six months) from the date of issue of the permit. This was viewed as less serious than the other two conditions, but it still meant that there was less flexibility in the timing of the venture.

During the interviews, it was found that only three of the respondents had any direct experience of a permit being refused for business purposes: two $(6,9 \%)$ were related to the occupation of premises while one $(3,5 \%)$ was related to the purchase of property. These incidents, however, dated back to the 1960 s; coinciding with the phase when there was much uncertainty as to the status of the Chinese people and when group areas for the Chinese were proclaimed in Kimberley, Port Elizabeth and Uitenhage. On subsequent applications, the permits were granted. The percentages of refusals were somewhat lower than those obtained, according to figures released in 1975 (Horrell, Hodgson, Blignaut \& Moroney, 1976: 219) for residential permits: $29,4 \%$ and $29,2 \%$ of the applicants were refused permits to occupy and to purchase respectively. However, it is possible that those who had been refused permits were underrepresented in the sample. Some of those who were unsuccessful might have decided to trade elsewhere or might have given up the idea of opening a business. On the other hand, it could also be that the rate of refusal for trading purposes was lower than that of permits for residential purposes. Another possibility is that the presence of Chinese group areas in the Cape might have resulted in more permits being refused there, influencing the general rate. Whatever the case, the fact still remains that the Chinese did not have full trading rights in the CBD because permits were required; with the possibility of refusals, together with the conditions attached to those that were granted, they became contributory factors to the uncertainties that had to be borne by the traders.

In 1984, the Chinese were granted the same rights as whites in terms of the Group Areas Act. This meant permits were no longer required by the Chinese to occupy and purchase fixed property in white areas. The major implication was that the possibility of refusal and the attached conditions were now no longer potential factors of hindrance. All of the respondents welcomed the move as a step in the right direction. However, the majority felt that it was something that should have taken place much earlier. It was also noted that many of the respondents viewed the step as merely an 'official blessing' of what the Chinese have been doing for a long time. The only difference or change was that the red tape associated with the application for permits was eliminated.
The marginal position of the Chinese in South Africa has already been mentioned. Throughout the interviews, experiences and opinions of the respondents were consistent with what has already been said about marginality as it relates to Chinese businesses. Although this study concentrated on a small section of the business com. munity, and thus represented only those who were at the time operating in the Johannesburg CBD, the following points were noted as particularly significant:

(a) The clearance of slums such as Sophiatown had resulted in the removal and dislocation of Chinese, Indian and coloured businesses and every effort was made to resettle the Indian and coloured traders in their own areas (Horrell, 1957: 105; Horrell, 1960: 143). In the case of the Chinese represented in this study, no great effort had been made to resettle this group in any particular area (white or non-white).

(b) Permits were granted, but some were refused in the 1960 s. In addition, the conditions which were attached to the permits prevented the automatic transfer of the concession to other persons, including members of the immediate family.

(c) During the decade of $1960 \mathrm{~s}$, the prospect of a Chinese group area in Johannesburg had been very real: Port Elizabeth, Uitenhage and Kimberley had already been affected at the time; Langlaagte and Willowdene were proposed as possible areas for the resettlement of the Chinese. If a group area had been proclaimed, the traders would have had to move from the white areas, and possibly even from the non-white areas. Until their position had been clarified, their businesses would face an uncertain future.

Under such circumstances, the Chinese were in an extremely ambiguous and uncertain position. The traders stood on the boundary between the white and non-white groups, (Gordon, 1964: 56 and Ziller, Stark \& Pruden, 1969). Unlike the white traders, they were allowed to resettle in non-white areas; like the non-white, they were required to apply for a permit to trade in white areas; but this was where the similarity ended. During the same period, Asian traders (Indians) were evicted from the white group areas (Horrell, 1960: 143-144). According to the respondents who were trading in these areas at the time, however, no such actions were taken against the Chinese as there was nowhere to resettle them, and in fact many Chinese from Sophiatown moved into these zones. Further, the respondents were able to move from one area into another without too much restriction.

Turning to the effects marginality on Chinese businesses, it would appear that the ambiguity of the position of the Chinese, together with the conditions attached to permits, has resulted in an unwillingness to invest extra money in the businesses. On this point, at least some of the respondents were of the opinion, or implied, that they had seen no reason for reinvesting profits into the business as their family might not have been able to benefit because of the conditions of the permits. This reinforces the findings of Human (1984: 54), who stated that ...many Chinese people would not allow their children to follow them into business, particularly in 
view of the fact that there is no guarantee that the father will be able to pass on his business to his son'. Other respondents were bitter about the unpredictability of such a situation. According to them they had been reluctant to invest in the past in the face of opportunities: in what could be termed 'strategic windows' (Abel \& Hammond, 1979: 63), they had the capital, the skill, or whatever key requirements were necessary, but with perplexity and reluctance only saw these opportunities disappear. Transferability and continuity of the business were such important issues possibly because of the tradition of passing the business onto the next generation (Dellatola, 1977: 54) and the common practice of nepotism which appeared to be universal among the Chinese (see for example, Economist, 1984: 82; Wu, 1983: 113). Perhaps uncertainty is also one of the reasons for the observation made by Human (1984: 554) that Chinese businesses remain quite small to this day.

Despite the negative effects that marginality has had on Chinese businesses, the marginal position of the Chinese might have given the trader certain alternatives that he otherwise would not have had. It has been theorized that Chinese businesses were in an advantageous position because the choice of geographic segments was not restricted when compared with traders from other racial groups where distinctions between white and nonwhite were clear. The histories and movements of the respondents have shown that even among this small group of businessmen, there was a percentage of those who have operated in both white and non-white areas before. Others have entered and traded in white areas, including the CBD, before, during, and after the height of the implementation of the Group Areas Act. The implication of this observation is that it is consistent with the notion that Chinese traders were less restricted than other population groups in the choice of locations.

If the areas are placed into segments in terms of Porter's (1985) concept, the competitive advantage of the Chinese businesses can be better understood when the forces of competition (Porter, 1980) are analysed.

The threat of entry can be viewed as the barriers to entry in the context of the respondents' environment. In the late 1950s and until well into the 1960s, the nonwhite traders (including the Chinese) were in disarray as a result of the implementation of the Group Areas Act and the clearance of slums.

The barrier to entry into white areas of Johannesburg was high for most of these traders since those already there were being evicted (Horrell, 1960: 143; Lemon, 1976: 115). As stated by the Deputy Minister of Interior at the time: 'Once an area has been proclaimed a group area for a particular group, further infiltration of members of other groups cannot be allowed' (Horrell, 1960: 143). However, the Chinese who had chosen to trade in white areas did so under the authority of a permit which appeared to be granted in most cases. For those Chinese who had chosen to enter non-white areas during that same period, the entry barrier (as it related to the actions and policies of the Government) into coloured townships was also low. Some of the respondents therefore went into these areas or had their first business experience there. The barrier was high for whites because they were unlikely to be granted permits to trade there. The barrier for all groups (including the Chinese) was high for black areas such as Soweto because, according to some respondents, only blacks were allowed to trade in the interiors of the township.

Turning to forces which are not directly associated with the Group Areas Act, and looking at the reasons which were given by the respondents for moving in or out of an area, it would appear that initially, capital requirement was one of the factors which prevented the entry of certain traders into white areas; their alternative was therefore to locate in non-white townships where not so much working capital was needed. Others were attracted by the high profit margin which was related to the low bargaining power of the buyers. However as time passed, some forces changed while other forces became more apparent or less tolerable. The bargaining power of the supplier was found to be high because the area was not an important customer, hence there were poor banking, transport and delivery facilities. The bargaining power of the buyers has also increased because they are able to shop further afield with improved means of transport: hence service needed to be improved through longer trading hours and possibly lower prices.

When the forces became intolerable or not manageable, the respondents looked for other areas where they could cope better with these forces, in other words, they are positioning their firms so that they are least affected, or where their capabilities provide the best defense against the array of competitive forces (Porter, 1980: 29-30). It was here that the marginal position of the Chinese enabled the Chinese traders to consider a wider range of options than others operating in the nonwhite areas. While the non-whites could only remain in the area - and use other strategies to cope - or move to another non-white area, these choices were also open for the Chinese, who in addition, could also move to white areas as other options. One of the options was the CBD of Johannesburg where the forces were perceived as better suited to the capabilities of some of the businesses; the Chinese were therefore able to move from segment to segment of the matrix - as opposed to the other traders who were restricted to certain segments of their own groups.

\section{The present situation}

While the status of the Chinese under the Group Areas Act has been clarified, the political position of the group still remains to be resolved; i.e. the Chinese do not have any form of political representation at this time.

On the business level, it would appear that Chinese could still open new businesses in non-white areas although they now have full business rights in white areas without the need of permits. Although none of the respondents in the sample have started or taken over a business in non-white areas since 1984 (the year in which the Chinese were granted their rights in white areas), these respondents suggested that there were no signs to indicate that Chinese businesses in non-white areas 
would be curtailed in any way at present. The major factors that hamper more Chinese from entering certain non-white areas, such as Alexandra and Kliptown, are the sporadic unrest and unstable conditions of those areas. At least $11(37,9 \%)$ of the respondents questioned said that they have left the option of operating in nonwhite areas open in case conditions improve and opportunities should exist. It would therefore appear that the barrier to entry into non-white areas has not altered although the status of the Chinese has been changed at least at the official level. The Chinese therefore still retain their competitive edge over their white counterparts as far as trading in non-white areas is concerned.

With the opening of the CBD, the barriers which previously protected traders of the area from entrance of non-white traders have now been lifted. None of the respondents have, however, noticed any major changes that affect their present businesses in any way. At this stage it would appear it is still too early for any measurable impact to be felt.

When the present situation of the Johannesburg CBD is analysed, it would appear that the Chinese still have a number of advantages. In coping with the threat of entry, the early entry of the existing Chinese businesses is an advantage in that (i) some of the respondents have secured favourable access to supplies: for example, some of the owners said that maintaining a good relationship or favourable contracts with the suppliers have ensured preferential treatment in times of shortage of certain materials, credit facilities have been extended, and discounts above normal levels have been received - such relationships needed time to build up and develop; (ii) favourable locations have been secured: for example, those respondents who were located in very busy areas, such as on the major pedestrian routes, have said that such locations were never easily available; (iii) the learning or experience curve is at a more advanced stage: for example, some respondents stated that the buying habits of the customers, their preferences, and various other factors were often different from one location to the next, even within the same vicinity; these have to be learnt through time.

In dealing with rivalry among competitors, some of the respondents who have had previous experience in competing against non-whites felt that their experience could come in useful and was an advantage when compared to white traders who were still trying to learn more about the new entrants. On the other hand, the nonwhites must also learn to compete against the whites. The Chinese, standing in a position between the two, knew more about the two groups than the groups knew about each other. Other respondents, however, felt that each situation is different, and hence their position is not useful. The truth of the matter probably lies somewhere between the two extremes; it is likely to depend on what the individual has learned, and how he puts his experience and knowledge to use. There were also some respondents who viewed the black and coloured traders as less competitive than the Indians or whites. This impression with regard to blacks probably came about because the respondents had very little experience in competing with black businesses. Blacks were limited by the Group Areas Act as well as a number of other laws which determined that such entrepreneurs could establish businesses only in their own separate areas, where they were protected against competition from outside (Cooper, et al., 1985: 219). A lack of business traditions, together with the restrictive nature of the laws which govern the business activities of non-whites, (Lemon, 1976: 136-138) may constitute the reasons behind the observations about the coloured businesses.

The bargaining power of the buyer, the bargaining power of the suppliers and the threat of substitutes may or may not be affected by the changes that result from the opening of the CBD. The opinions of the respondents were divided on these issues. While some of the traders felt that the buying patterns of the customers may change, for example, should blacks prefer to patronize stores belonging to blacks (to take one extreme), others were of the opinion that they have built up enough customer loyalty to sustain their competitive position. As for the suppliers, higher demand for certain goods by the new entrants may increase the price of these goods, but again, such remarks were based on speculation rather than facts or actual experiences. Apart from the advantages associated with early entry into the $\mathrm{CBD}$, the marginal position appeared to bring no significant advantages (over other groups) in dealing with the bargaining power of the buyers or that of the suppliers, and in facing the threat of substitutes, unless for the purpose of moving into another area where the business can cope with these forces from a more advantageous position.

The most significant negative effect which resulted from the marginal position of the Chinese, or the uncertainties associated with it, was the reluctance to invest more than the necessary capital into the future of the business. Human (1984: 54) has identified that children were not encouraged to follow their parents into business for the same reasons. Some of the comments made by the respondents still contained certain elements of uncertainty and have highlighted the fact that marginality is present even in the light of the current situation of freetrading in the CBD and trading rights in other white areas. The following are examples of the remarks made by a few of the respondents:

'The government may once again change its mind about the rights of the Chinese if it is forced to retreat to its former policies for any reason'.

'If the right wing elements of the white population should come into power, Chinese will once again be regarded as non-whites and will thus lose everything they have gained so far: including business rights in white areas. If blacks should take over the government, the Chinese will be seen as co-conspirators with the whites - reinforced by the fact that Chinese enjoy the same privileges as whites'.

'The options of trading in non-white locations could be reduced anytime now that full trading rights are given in white areas'.

'Blacks are enjoying special treatment in educational 
programmes, loans, and subsidies in their business ventures. They could therefore overtake the Chinese one day. Whites already hold the economic edge and are far ahead of the Chinese. Therefore we are the loser at the end of the day'.

'I read about changes in the newspapers, but nothing has really changed - I am still unlikely to get a licence for a bottle store or a gun shop because I'm Chinese. That is why we have to run fish and chips shops and eating houses, which we have always been able to do'.

By way of contrast, four of the respondents who were interviewed came from successful professional backgrounds which were unrelated to their present businesses: an accountant who now operates a butchery, a former industrial microbiologist who runs another butchery, a computer engineer who manages a delicatessen, and a second accountant who has opened up a shoe repair business. They all have one reason in common for their departure from the career for which they had been trained: an own business is viewed as a more profitable long-term investment than working for someone else. In all cases, the element of uncertainty, as it relates to the position and future of the Chinese business, did not seem to be present. One respondent has in fact persuaded his two brothers, who were also professional men, to join him. Another was (at the time of the interview) in the final stages of negotiating new premises for a second branch of his business. Although only one of the respondents has indicated that the clarification of his status and the newly acquired business rights have influenced his decision, the rest nevertheless indirectly implied that the abolition of the permit system has boosted their ability to seek a niche in an environment that is essentially white. The actions of these four respondents may or may not be significant as an indicator of a new trend, but they do show that at least some element of confidence is present.

Although only the extreme cases have been presented to illustrate some of the attitudes towards the changes that have taken place, the majority of the respondents were either disinterested or unaffected by the implications of the legal status of the Chinese or the opening of the CBD. This can be compared with the finding by Human (1984: 86) that amongst the merchants, the defense mechanism against the inconsistencies of their position in society was a strong motivation to achieve and succeed in economic terms, or that they are disinterested and unperturbed by such inconsistencies.

\section{Conclusions}

When the Johannesburg CBD was proclaimed a free trading area in February 1986, the legal barrier, which had previously protected Chinese traders operating within the CBD from other 'non-white' competitors, was removed.

It would appeat that the marginal position of the Chinese enabled businessmen to overcome some of the barriers set up by the Group Areas Act. Although a significant competitive advantage, which would have allowed strong penetration into more areas than any other racial group, existed, Chinese businesses have nevertheless remained small. This finding can be explained in terms of the negative aspects of the marginal position, namely, uncertainty, which impeded the development and progress of Chinese businesses.

Although, since the opening of the CBD, no changes in the competitive environment have been perceived by the respondents, it may be too early at this stage to gauge the impact of the move. Arising from the advantage of early entry, some of the businesses have (either consciously or unintentionally) managed to build certain barriers to entry around themselves; namely, (i) favourable access to supplies through developing and maintaining a good relationship with suppliers; (ii) securing of important strategic locations; and (iii) a more advanced stage along the learning curve.

The respondents were divided as to whether their marginal position had any advantage in dealing with rivalry among competitors. Although some of those who had traded in non-white areas felt that their previous experiences could be useful in dealing with the new entrants from these groups, others were of the opinion that the situations are entirely different. Hence it would appear that the advantage would depend on the circumstances, the type of experience, and the individual.

The Chinese retain, however, the ability to move from one area to another and, unlike white traders, can still trade in areas for 'non-whites'. These groups represent extremely important clients of the CBD, mainly in view of the lack of shopping facilities within 'non-white' areas. If free trading should also be introduced in 'non-white' areas, shopping facilities in these areas may improve, and black and coloured customers may shift their spending power from the CBD to their own areas. This in turn will alter the present balance of competitive forces within the respective segments. With regard to the Chinese, their marginal position and its relevance to competitive advantage would no longer exist. As for the Chinese businessmen in the CBD, six out of ten were dependent on black and coloured customers. Hence, any changes in legislation will affect a large number of Chinese businesses in the CBD.

Chinese businessmen, if they act now, have the opportunity to pre-empt the movement of white entrepreneurs into 'non-white' areas. They could do this by competing more broadly, whilst retaining their interests in the CBD. Future changes will, however, no doubt undermine the competitive advantage of the Chinese. It is therefore in the interests of these businessmen that they reconsider their position while they still have time.

\section{References}

Abell, D.F. 1980. Defining the Business: The Starting Point of Strategic Planning. New Jersey, Prentice Hall.

Abell, D.F. \& Hammond, J.S. 1979. Strategic Market

Planning: Problems and Analytical Approaches. New

Jersey: Prentice-Hall.

Arnold, D.R., Capella, L.M. \& Smith, G.D. 1983. Strategic

Retail Management. Reading, Massachusetts:

Addison-Wesley Publishing Co. 
The Black Market Book. 1983. Johannesburg: The Marketing Division of the Argus Printing and Publishing Co. Ltd.

Collins, F. (compiled by), 1970. Its status quo for Wong Fung Ho. Personality. 8 October, 44-47.

Cooper, C., Schindler, J., McCaul, C., Potter, F. \& Cullum, M. 1985. Race Relations Survey 1984. Johannesburg: SAIRR.

Dellatola, L. 1977. Chinese of Kimberley. S. Afr. Panorama, 22, 44-47.

Dickie-Clark, H.F. 1966. The Marginal Situation: A Sociological Study of a Coloured Group. London: Routledge and Kegan Paul.

The Economist. 1984. Business Brief. The Chinese abroad - rich not red. 219(7339), April 28, 82-83.

Gordon, M.M. 1964. Assimilation in American Life: The role of Race. Religion, and National Origins. New York: Oxford University Press.

Horrell, M. 1957. A Survey of Race Relations: 1956-57. Johanneburg: SAIRR.

Horrell, M. 1960. A Survey of Race Relations: 1959-60. Johannesburg: SAIRR.

Horrell, M. \& Hodgson, T. 1976. A Survey of Race Relations: 1975. Johannesburg: SAIRR.

Horrell, M., Hodgson, T., Blignaut, S. \& Moroney, S. 1977. A Survey of Race Relations: 1976. Johannesburg: SAIRR.

Human, L. 1984. The Chinese People of South Africa: Freewheeling on the fringes. Pretoria: UNISA.
Johnston, R. 1976. The Concept of the 'Marginal Man': A Refinement of the term. Austr. \& N.Z. J. Soc., 12, June, 145-147.

Lemon, A. 1976. Apartheid. Westmead, England: Saxon House.

Park, R.E. 1928. Human migration and the marginal man. Am. J. Soc., 33, 881-893.

Porter, M.E. 1980. Competitive Strategy: Techniques for Analyzing Industries and Competitors. New York: The Free Press.

Porter, M.E. 1985. Competitive Advantage: Creating and Sustaining Superior Performance. New York: The Free Press.

Smedley, L.N. 1978. The Chinese Community in South Africa: Phase 2: A Sociological Study. Pretoria: HSRC (S-50).

Stonequist, E.F. 1937. The Marginal Man. New York: Scribners.

Van Reenen, T.H. 1962 (updated 1981). Land: Its ownership and occupation in South Africa. Cape Town: Juta and Co. Ltd.

Wu, Y.L. 1983. Chinese Entrepreneurs in Southeast Asia. Am. Econ. Rev., 73, 112-117.

Yap, M. 1977. Portrait of SA's Chinese. Inside Mail, Rand Daily Mail. 7 February, 9.

Ziller, R.C., Stark, B.J. \& Pruden, H.O. 1969. Marginality and Integrative Management Positions. Acad. Manage. J., 12 December, 487-495. 